\title{
PENGARUH DISIPLIN KERJA TERHADAP KINERJA KARYAWAN PT. PERKEBUNAN NUSANTARA XIII PABRIK MINYAK SAWIT PASER BELENGKONG
}

\author{
Amir Hamzah \\ Program Studi Manajemen, Sekolah Tinggi Ilmu Ekonomi Widya Praja, Tanah Grogot, \\ Indonesia, hamzahassegaf69@gmail.com \\ Wahyudi ${ }^{2}$ \\ Program Studi Manajemen, Sekolah Tinggi Ilmu Ekonomi Widya Praja, Tanah Grogot, \\ Indonesia, yuditujuh@gmail.com \\ Eliana $^{3}$ \\ Program Studi Manajemen, Sekolah Tinggi Ilmu Ekonomi Widya Praja, Tanah Grogot, \\ Indonesia,yanaeli111@gmail.com
}

\begin{abstract}
Background - Humans are company assets that must be nurtured and directed in order to achieve the company's goals. Its implementation refers to company regulations that have been formulated and endorsed by company management. The disciplinary factor is one that affects human resources.

Purpose - This research aims to determine and analyze Effect of Work

Diterima : 20 Oktober 2020

Direview : 09 November 2020

Direvisi : 01 Desember 2020

Disetujui : 22 Januari 2021

Discipline on Employee Performance in Nusantara Plantations XIII. Palm Oil Factory Paser Belengkong, East Kalimantan

Design/ Methodology/ Approach - This type of research is quantitative research. Sample taken counted 109 respondents by using Proportionate stratified random sampling and simple random sampling. Data collection is taken by using some technique that is observation, interview and questionnaire by using Likert scale, statistical analysis using Statistical Product and Service Solutions (SPSS) version 20.

Result and discussion - Based on the calculation and test results, the highest work discipline variable is the preventive discipline variable $\left(X_{1}\right)$ partially influencing employee performance with $t$ count $8.720>t$ table 1.6595. Work discipline variable simultaneously affects employee performance with $F$-count 66.929> F table 2.69. The next test results based on determination coefficient obtained $R^{2}$ of 0.657 or $65.7 \%$, which means that $65.7 \%$ of the dependent variable, namely Employee Performance ( $Y$ ) is influenced by independent variables consisting of Preventive Discipline $\left(X_{1}\right)$, Corrective Discipline $\left(X_{2}\right)$ and Progressive Discipline $\left(X_{3}\right)$, while the remaining $34.3 \%$ is influenced by other variables not included in this study.

Research Implications - It is expected from the research results can benefit the company in paying attention to discipline to improve employee performance and besides that it can contribute to knowledge.

Limitations - This research was only conducted at PT Perkebunan Nusantara XIII Olongpinang Palm Oil Mill, Paser Belengkong Subdistrict, East Kalimantan with part of the respondents being employees so that further research is needed to expand the population.
\end{abstract}

Keyword: Work, Discipline, Employee, Performance, Perkebunan, Nusantara

\begin{abstract}
ABSTRAK
Latar Belakang - Manusia merupakan aset perusahaan yang harus dibina dan diarahkan agar tercapai tujuan perusahaan tersebut. Pelaksanaannya mengacu kepada peraturan perusahaan yang telah dirumuskan dan disahkan oleh manajemen perusahaan. Faktor disiplin termasuk salah satu yang berpengaruh pada sumber daya manusia.

Tujuan - Penelitian ini bertujuan untuk mengetahui dan menganalisis Pengaruh Disiplin Kerja terhadap Kinerja Karyawan PT Perkebunan Nusantara XIII Pabrik Minyak Sawit Kecamatan Paser Belengkong Kalimantan Timur.
\end{abstract}


Desain/ metodologi/ pendekatan - Jenis penelitian yang digunakan adalah penelitian kuantitatif. Sampel yang diambil sebanyak 109 responden dengan menggunakan Proportionate stratified random sampling dan simple random sampling. Pengumpulan data dilakukan dengan menggunakan beberapa teknik yaitu observasi, wawancara dan kuesioner dengan menggunakan skala likert, analisis statistik menggunakan Statistical Product and Service Solutions (SPSS) versi 20.

Hasil dan pembahasan - Berdasarkan hasil perhitungan dan hasil pengujian diperoleh variabel disiplin kerja tertinggi yaitu variabel disiplin preventif $\left(\mathrm{X}_{1}\right)$ secara parsial memiliki pengaruh terhadap variabel kinerja karyawan dengan $\mathrm{t}$ hitung 8,720>t tabel 1,6595. Variabel disiplin kerja secara simultan memiliki pengaruh terhadap variabel kinerja pegawai dengan Fhitung 66,929> F tabel 2,69. Hasil pengujian selanjutnya berdasarkan koefisien determinasi diperoleh $\mathrm{R}^{2}$ dengan nilai 0,657 atau persentasenya adalah $65,7 \%$ yang berarti bahwa berarti $65,7 \%$ variabel dependen yaitu variabel kinerja karyawan (Y) dipengaruhi oleh variabel independen yang terdiri dari variabel disiplin preventif $\left(\mathrm{X}_{1}\right)$, variabel disiplin Korektif $\left(\mathrm{X}_{2}\right)$ dan variabel disiplin Progresif $\left(\mathrm{X}_{3}\right)$, sedangkan sisanya $34,3 \%$ ada pengaruh dari variabel lain diluar dari penelitian ini.

Implikasi Penelitian - Diharapkan dari hasil penelitian ini dapat memberi manfaat bagi perusahaan agar lebih memperhatikan disiplin untuk meningkatkan kinerja karyawan dan selain itu bisa memberikan sumbangsih terhadap ilmu pengetahuan.

Batasan Penelitian - Penelitian ini hanya dilakukan di PT Perkebunan Nusantara XIII Pabrik Minyak Sawit Olongpinang Kecamatan Paser Belengkong Kalimantan Timur dengan responden sebagian karyawan sehingga masih perlu penelitian lanjutan untuk memperluas populasi.

Kata Kunci: Disiplin, Kerja, Kinerja, Karyawan, Perkebunan, Nusantara

\section{PENDAHULUAN}

Sumber daya manusia memiliki peran yang cukup penting baik secara individu ataupun kelompok, dan juga merupakan faktor utama atas efektifnya seluruh kegiatan sebuah perusahaan agar dapat berjalan dengan baik. Keberhasilan perusahaan dalam mengatur dan memberdayakan sumber daya manusia yang merupakan aset perusahaan yang dapat meningkatkan penghasilan perusahaan sehingga perusahaan dapat bertahan dan memenangkan persaingan dengan perusahaan lain yang sejenis. Kunci dari keberhasilan perusahaan dalam hal ini tidak terlepas dari faktor manusia sebagai variabel yang mempunyai pengaruh sangat besar dan menentukan maju tidaknya perusahaan. Manusia merupakan aset perusahaan yang harus terus dibina dan diarahkan agar perusahaan dapat mencapai tujuan yang diinginkan. Pelaksanaanya mengacu kepada tata tertib dan peraturan perusahaan yang telah dirumuskan dan disahkan oleh manajemen perusahaan.

Salah satu faktor yang mempengaruhi sumber daya manusia adalah faktor disiplin. Disiplin merupakan kegiatan yang dilakukan manajemen untuk dapat menjalankan standar-standar organisasial. (Hamali, 2018) Disiplin adalah salah satu prosedur agar dapat menghadapi permasalahan yang terdapat dalam kinerja, yang mana dalam pelaksanaanya ada peran manajer dalam melakukan identifikasi dan komunikasi semua masalah kinerja di hadapan semua pegawai. (Robert Bacal, dikutip dalam Fahmi, 2013). Apabila permasalahan kineja tidak dilakukan perbaikan, maka manajer turut serta dalam melakukan identifikasi, 
komunikasi, dan menerima segala konsekuensi (Sinambela, 2016).

Disiplin kerja yang dilaksanakan dengan baik oleh para karyawan akan mampu menciptakan kinerja karyawan yang positif, sehingga perusahaan dapat mencapai tujuan yang telah ditetapkannya. Maka dari itu setiap perusahaan harus lebih banyak perhatian dan melakukan pengaturan atas seluruh karyawannya sebagai langkah untuk meningkatkan kinerja yang baik. Kinerja (prestasi kerja) diartikan sebagai hasil pekerjaan baik kualitas maupun kuantitas yang diraih oleh pegawai dalam menjalankan pekerjaannya berdasarkan tanggung jawab yang diberikan kepadanya. (Mangkunegara, 2013)

Masalah yang terjadi pada PT Perkebunan Nusantara XIII (PTPN XIII) Persero Pabrik Minyak Sawit Olongpinang adalah kurangnya tingkat disiplin kerja dari para karyawannya. Hal tersebut di tandai dengan karyawan yang masuk kerja tidak sesuai dengan peraturan yang ada di dalam perusahaan yaitu datang terlambat dan pulang kerja tidak sesuai dengan jadwal yang sudah dibuat oleh perusahaan.

PTPN XIII (Persero) Pabrik Minyak Sawit Olongpinang adalah salah satu perusahaan BUMN (Badan Usaha Milik Negara) unit Pabrik Minyak Sawit Olongpinang Distrik Kalimantan Timur beralamat di Desa Olongpinang Kecamatan Paser Belengkong Kabupaten Paser Provinsi Kalimantan Timur. Pabrik Minyak Sawit Olongpinang didirikan pada tahun 1991 berdasarkan Kontrak Nomor : 06 DIR/SP/56/1991 Tanggal 01 juni 1991 dengan pendirian IMB dari Bupati KDH Tk.II Paser Nomor 647/036/Bang - Tahun 1992 Tanggal 2 Mei 1992 dan pendirian selesai di bangun pada bulan September 1994.

Berikut data karyawan PTPN XIII (Persero) Pabrik Minyak Olongpinang. Karyawan yang saat ini berkerja di PT. Perkebunan Nusantara XIII (Persero) Pabrik Minyak Sawit Olongpinang sudah melalui proses seleksi dan telah memiliki berbagai kemampuan yang didapat dari training (pelatihan) yang dilaksanakan di dalam atau di luar perusahaan. Akan tetapi pelatihan saja tidak cukup, perlu adanya peningkatan softskill yang dapat menjadi nilai tambah bagi karyawan tersebut, misal kemampuan untuk berkomunikasi, berkerja sama, jujur, ulet, dan percaya diri dalam menyelesaikan suatu pekerjaan dengan disertai oleh sikap disiplin kerja sehingga kinerja karyawan di perusahaan secara optimal bisa tercapai.

Adapun masalah yang terjadi pada PT. Perkebunan Nusantara XIII (Persero) Pabrik Minyak Sawit Olongpinang adalah kurangnya tingkat disiplin kerja dari para karyawannya. Hal tersebut dilihat dari beberapa karyawan yang masuk kerja terlambat dan pulang kerja tidak sesuai dengan ketetapan jadwal yang sudah dibuat oleh perusahaan. PTPN XIII (Persero) Pabrik Minyak Sawit Olongpinang menetapkan jam masuk dan pulang karyawan mulai pukul 
07.00-16.00 WITA. Tetapi masih ada karyawan yang melanggar peraturan tersebut. Untuk lebih jelasnya dapat dilihat dari data jumlah karyawan yang melanggar disiplin kerja yang terjadi pada PTPN XIII (Persero) Pabrik Minyak Sawit Olongpinang seperti pada tabel berikut ini.

Pada Tabel 2 dapat dilihat tingkat pelanggaran disiplin kerja karyawan dalam lima bulan dari Januari hingga Mei tahun
2020 terdapat jumlah rata- rata karyawan terlambat masuk kerja adalah sebanyak 38 orang dan jumlah rata-rata karyawan yang tidak masuk kerja sebanyak 49 orang. Dengan adanya kondisi tersebut, hal ini tentu saja akan mempengaruhi kinerja masing-masing karyawan. Tingkat kondisi disiplin kerja yang rendah akan membuat terhambat tujuan dari perusahaan.

Tabel 1

Data Karyawan PTPN XIII (Persero) Pabrik Minyak Sawit Olongpinang Tahun 2020

\begin{tabular}{l|c}
\multicolumn{1}{|c|}{ Jenis Karyawan } & Jumlah \\
Manager & 1 \\
Karyawan Pimpinan & 6 \\
Karyawan Pelaksana Admin & 9 \\
Keamanan & 8 \\
Teknik & 26 \\
Transport & 10 \\
Pengolahan & 69 \\
Harian Pengolahan & 4 \\
Mutu / Laboratorium & 16 \\
\hline \multicolumn{1}{c}{ Total Karyawan } & 149 \\
\hline
\end{tabular}

Sumber : Data Internal PTPN XIII (Persero) Pabrik Minyak Sawit Olongpinang

Tabel 2

Data Pelanggaran Disiplin Kerja Karyawan PT. Perkebunan Nusantara XIII (Persero) Pabrik Minyak Sawit Olongpinang Januari - Mei Tahun 2020

\begin{tabular}{l|r|r} 
Bulan & $\begin{array}{r}\text { Rata-rata jumlah karyawan } \\
\text { terlambat masuk kerja / bulan }\end{array}$ & \multicolumn{2}{c}{$\begin{array}{c}\text { Rata-rata Jumlah karyawan } \\
\text { tidak masuk kerja / bulan }\end{array}$} \\
\hline Januari & 10 Orang & 13 Orang \\
Februari & 12 Orang & 17 Orang \\
Maret & 8 Orang & 8 Orang \\
April & 4 Orang & 4 Orang \\
Mei & 4 Orang & 7 Orang \\
\hline Jumlah & 38 Orang & 49 Orang
\end{tabular}

Sumber : Data Internal PT.Perkebunan Nusantara XIII (Persero) Pabrik Minyak Sawit Olongpinang

TINJAUAN PUSTAKA

Manajemen Sumber Daya Manusia
Manajemen sumber daya manusia adalah suatu bidang manajemen yang mana di dalamnya membahas tentang hubungan 
serta peran serta manusia di dalam sebuah organisasi perusahaan. Unsur yang terdapat pada manajemen sumber daya manusia adalah manusia yang merupakan tenaga kerja pada perusahaan. Dengan demikian, yang menjadi pembahasan utama pada manajemen sumber daya manusia adalah permasalahan yang ada kaitannya dengan kerja manusia saja. Hasibuan (2013) mengungkapkan agar dapat berjalan dengan efektif dan efisien serta tercapai tujuan perusahaan sehingga bermanfaat bagi masyarakat maka perlu adanya pengetahuan yang dapat mengatur hubungan dan peranan tenaga kerja di dalam manajemen sumber daya manusia.

\section{Disiplin Kerja}

Kedisiplinan merupakan bagian penting dari manajemen sumber daya manusia karena jika kedisiplinan karyawan baik maka dapat menghasilkan sebuah prestasi kerja atas hasil kerja karyawan tersebut. Menurut Hasibuan (2013) kedisiplinan adalah bagaimana seseorang dalam kesadarannya dan atas kemauannya sendiri patuh atas segala peraturan dan norma-norma yang diberlakukan perusahaan. Menurut Bacal dalam Sinambela (2016) disiplin adalah sebuah proses yang bisa dipakai jika terdapat masalah dalam kinerja. Apabila masalah kinerja tidak dilakukan perbaikan, ada keterlibatan manajer dalam melakukan identifikasi, komunikasi, dan menerapkan segala bentuk konsekuensinya. Dapat diberi kesimpulan bahwa disiplin kerja adalah proses yang diterapkan agar terbiasa mengatasi masalah yang terdapat pada kinerja organisasi perusahaan sebagai suatu bentuk pelatihan untuk membenahi dan melakukan pembentukan pengetahuan, perubahan karakter ke arah positif dan perbaikan perilaku karyawan sehingga bisa bekerja secara terus menerus guna mewujudkan tujuan perusahaan. Menurut Handoko (2011) mengatakan ada tiga indikator disiplin kerja, diantaranya:

1. Disiplin preventif adalah suatu tindakan yang dilakukan untuk membuat karyawan tergerak untuk mematuhi berbagai peraturan sehingga dapat mencegah terjadinya pelanggaran. Sasarannya adalah guna menggerakkan sikap disiplin individu para karyawan. Disiplin preventif menjaga disiplin diri karyawan hingga tidak ada keterpaksaan karyawan dalam menjalankan peraturan

2. Disiplin korektif adalah suatu tindakan yang dilakukan untuk penanganan atas segala bentuk pelanggaran terhadap peraturan sehingga bisa menghindari bentuk pelanggaran lebih lanjut. Disiplin korektif ini dalam bentuk hukuman yang diberikan dan beri istilah pendisiplinan (disciplinary action).

3. Perusahaan dapat membuat sebuah kebijaksanaan dalam bentuk disiplin progresif, artinya ada konsekuensi atas pelanggaran berulang yang dilakukan karyawan dalam bentuk hukuman berat. 
Tujuannya agar ada kesempatan bagi karyawan untuk memperbaiki kesalahannya sebelum ada bentuk hukuman yang lebih berat. Secara ringkas Sistem disiplin progresif seperti berikut ini:
a. Teguran secara lisan oleh penyelia.
b. Teguran tertulis, dengan catatan dalam file personalia.
c. Skorsing satu hingga tiga hari.
d. Skorsing satu minggu atau lebih.
e. Diturunkan pangkatnya (demosi).
f. Dipecat

\section{Kinerja Karyawan}

Kinerja adalah sesuatu yang penting bagi perusahaan, khususnya kinerja karyawan yang bisa membawa perusahaan pada pencapaian tujuan yang diharapkan. Menurut Mangkunegara (2013) kinerja adalah hasil kerja dari pegawai baik secara kualitas maupun kuantitas yang diraihnya dalam menjalankan tugasnya sesuai dengan tanggung jawab yang diberikan kepadanya. Jadi kinerja merupakan suatu hasil kerja yang dicapai seseorang dalam melaksanakan tugas-tugas yang diberikan kepadanya berdasarkan kesungguhannya dalam menjalankan tugas tersebut. Menurut Amstrong dalam Fahmi (2011) kinerja merupakan hasil dari sebuah pekerjaan yang erat hubungannya dengan tujuan strategis dari organisasi, kepuasan konsumen dan memberikan kontribusi ekonomi. Maka dapat disimpulkan bahwa kinerja adalah prestasi kerja secara kualitas dan kuantitas yang mempunyai hubungan kuat dengan tujuan strategi orgaisasi, kepuasan konsumen, dan memberikan kontribusi ekonomi untuk mencapai tujuan organisasi.

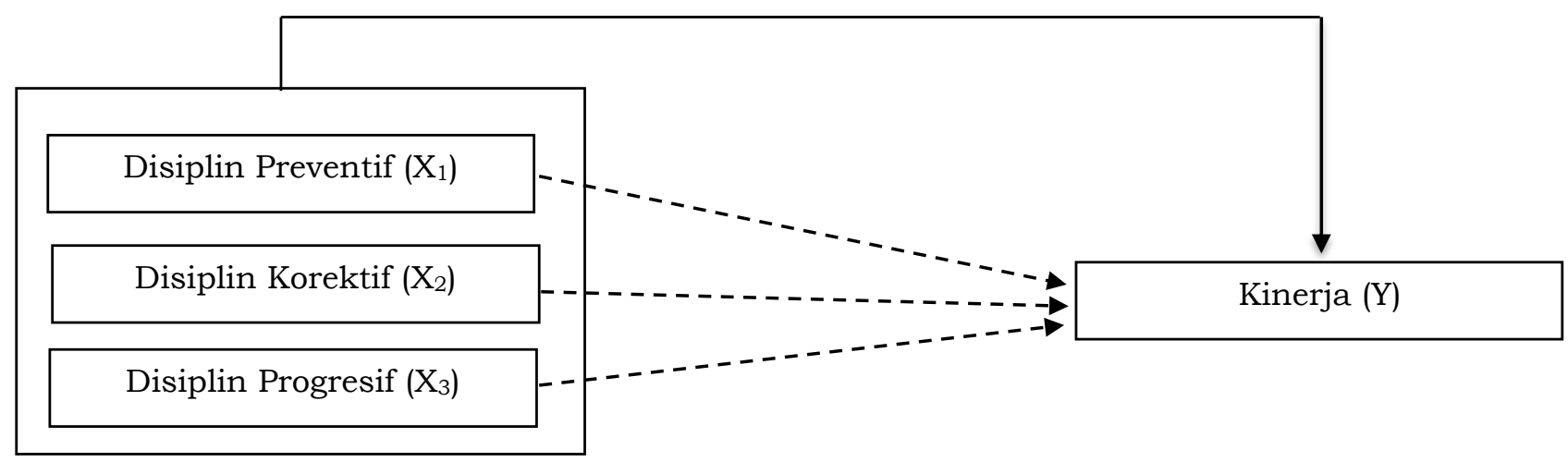

Keterangan:

Gambar 1 Model Penelitian

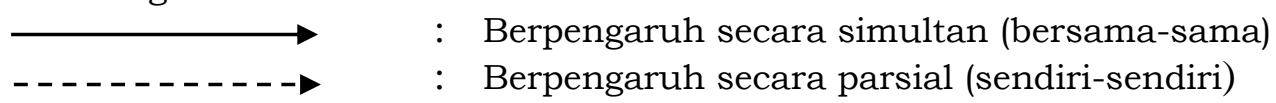

Kinerja adalah hasil dari sebuah proses yang mengacu dan diukur selama periode kurun waktu tertentu berdasarkan ketentuan atau 
kesepakatan yang telah ditetapkan sebelumnya (Edison et al., 2016). Penelitian yang dilakukan oleh Puspitasari dan Prahiawan, (2018) Menyatakan bahwa disiplin preventif memiliki pengaruh yang positif dan signifikan terhadap kinerja karyawan dengan koefisien jalur disiplin preventif terhadap kinerja adalah 0,535. Hal ini berarti setiap peningkatan disiplin preventif sebesar satu satuan, maka akan meningkatkan kinerja sebesar 0,535. Begitu pula Penelitian Safitriani (2016) menunjukkan bahwa dispilin preventif berpengaruh positif dan signifikan terhadap kinerja karyawan. Hal ini menunjukkan karyawan pada perusahaan tersebut mengetahui akan tujuan dan kemampuan karena dua hal tersebut sangat penting untuk meningkatkan kinerja organisasi, maka dapat disimpulkan:

H1: Terdapat pengaruh disiplin preventif secara parsial terhadap kinerja karyawan pada PTPN XIII (Persero) Pabrik Minyak Sawit Olongpinang Di kecamatan Paser Belengkong.

Disiplin korektif adalah upaya untuk menggerakkan pegawai dalam menyatukan suatu peraturan dan mengarahkan untuk tetap mematuhi peraturan sesuai dengan pedoman yang berlaku dalam instansi (Prabu Mangkunegara, 2013). Penelitian yang dilakukan oleh Pratiwi, dkk, (2017) menunjukkan disiplin korektif memiliki kriteria jawaban baik. Cara memperbaikinya adalah memberikan tindakan tegas bagi karyawan yang melakukan pelanggaran yang sama misalnya pemberian surat peringatan bertahap. Dengan demikian, disiplin korektif cukup efektif dalam memperbaiki kinerja karyawan. Penelitian lain oleh Sanjaya (2016) menunjukkan bahwa disiplin korektif memiliki pengaruh yang positif signifikan terhadap kinerja karyawan dengan koefisien jalur disiplin korektif terhadap kinerja adalah 0,2417. Hal ini berarti setiap peningkatan disiplin korektif sebesar satu satuan, maka akan meningkatkan kinerja sebesar 0,2417, dapat disimpulkan:

H2: Terdapat pengaruh disiplin korektif secara parsial terhadap kinerja karyawan pada PTPN XIII (Persero) Pabrik Minyak Sawit Olongpinang Di kecamatan Paser

\section{Belengkong.}

Disiplin progresif memberikan disiplin yang secara progresif lebih keras untuk contoh-contoh tingkah laku tidak tepat yang diulangi. Program ini mulai dengan peringatan lisan pada saat pelanggaran pertama kali dilakukan. Peringatan ini hendaknya diberikan dengan halus sebagai kesempatan bagi karyawan untuk mengoreksi tingkah lakunya sebelum ada konsekuensi serius yang timbul. Macammacam disiplin yaitu peringatan lisan, peringatan tertulis, skorsing disipliner, pembebasan kerja, dan penurunan pangkat (Strauss and Sayles, 1977). Penelitian yang dilakukan oleh Puspitasari dan Prahiawan (2018) menyatakan bahwa disiplin progresif berpengaruh negatif terhadap kinerja 
pegawai. Pada penelitian yang dilakukan Poma (2014), ada pengaruh disiplin pegawai terhadap kinerja karena bagian dari disiplin progresif seperti pengawasan langsung dari atasan serta pemberian sangsi kepada pegawai yang melanggar aturan. Pada penelitian lain yang dilakukan oleh Wiguna (2018) ada pengaruh yang positif dan signifikan antara disiplin progresif terhadap kinerja karyawan Colony Corner Bandung sebesar 0,768. Hal ini berarti setiap peningkatan disiplin progresif sebesar satu satuan, maka akan meningkatkan kinerja sebesar 0,768, dapat disimpulkan:

H3: Terdapat pengaruh disiplin progresif secara parsial terhadap kinerja karyawan pada PTPN XIII (Persero) Pabrik Minyak Sawit Olongpinang Di kecamatan Paser Belengkong.

Menurut Handoko (2011) yang menggolongkan disiplin menjadi tiga macam yaitu disiplin preventif, disiplin korektif dan disiplin progresif menyatakan bahwa kedisiplinan sangat diperlukan oleh sebuah organisasi karena dengan adanya kedisiplinan maka karyawan akan bersedia untuk menaati dan melaksanakan peraturan yang sudah dibuat organisasi dan siap menerima sanksi atas pelanggaran sesuai yang sudah ditetapkan organisasi. Penelitian yang dilakukan oleh (Safitriani, 2016); (Husna, 2017) variabel disiplin preventif, korektif atau positif dan progresif secara bersama-sama berpengaruh terhadap kinerja pegawai. Dapat disimpulkan:
H4: Terdapat pengaruh disiplin preventif, disiplin korektif dan disiplin progresif secara simultan terhadap kinerja karyawan pada PTPN XIII (Persero) Pabrik Minyak Sawit Olongpinang Di kecamatan Paser Belengkong.

\section{METODOLOGI PENELITIAN}

Penelitian ini menggunakan pendekatan kuantitatitif. Tujuannya adalah untuk menentukan hubungan antar variabel dalam sebuah populasi. Pendekatan kuantitatif pada penelitian ini menggunakan metode survei. Sugiyono (2017) Metode survei adalah Penelitian yang dilakukan dengan menggunakan angket sebagai alat penelitian yang dilakukan pada populasi besar maupun kecil, tetapi data yang digunakan adalah data dari sampel yang diambil dari populasi tersebut, sehingga ditemukan kejadian relatif, distribusi, dan hubungan antar variabel, sosiologis maupun psikologis.

Teknik pengambilan data dalam penelitian ini menggunakan kuesioner dan diukur menggunakan skala likert. Menurut Sugiyono (2017) Skala Likert digunakan untuk pengukuran terhadap sikap, pendapat, dan persepsi seseorang atau kelompok orang tentang fenomena sosial. Dalam penelitian, fenomena sosial ini telah ditetapkan secara spesifik oleh peneliti, yang selanjutnya di sebut sebagai variabel penelitian. Dengan skala likert, maka variabel yang akan diukur dijabarkan menjadi indikator variabel. Kemudian 
indikator tersebut dijadikan sebagai titik tolak untuk menyusun item-item instrument yang dapat berupa pernyataan atau pertanyaan. Tabel 3 akan menjelaskan skor pada skala Likert.

Tabel 3

Skala Likert

\begin{tabular}{l|c}
\multicolumn{1}{c|}{ Uraian } & Nilai Likert \\
Sangat Setuju & 5 \\
Setuju & 4 \\
Ragu-ragu & 3 \\
Tidak Setuju & 2 \\
Sangat Tidak setuju & 1 \\
\hline Sumber : Sugiyono $(2017)$ &
\end{tabular}

Tabel 4

Penentuan Jumlah Sampel pada Karyawan PT. Perkebunan Nusantara XIII (Persero) Pabrik Minyak Sawit Olongpinang

\begin{tabular}{l|c|c}
\multicolumn{1}{c}{ Populasi } & Jumlah Karyawan & Sampel \\
\hline Manager & 1 & $1 / 149 \times 109=1$ \\
Karyawan Pimpinan & 6 & $6 / 149 \times 109=4$ \\
Karyawan Pelaksana Admin & 9 & $9 / 149 \times 109=7$ \\
Keamanan & 8 & $8 / 149 \times 109=6$ \\
Teknik & 26 & $26 / 149 \times 109=19$ \\
Transport & 10 & $10 / 149 \times 109=7$ \\
Pengolahan & 69 & $69 / 149 \times 109=50$ \\
Harian Pengolahan & 4 & $4 / 149 \times 109=3$ \\
Mutu / Laboratorium & 16 & $16 / 149 \times 109=12$
\end{tabular}

Sumber : Data Internal PT. Perkebunan Nusantara XIII (Persero) Pabrik Minyak Sawit Olongpinang

Alat analisis yang digunakan adalah uji $\mathrm{T}$ (uji koefisien regresi secara parsial), uji $\mathrm{F}$ (uji koefisien regresi secara bersama-sama), uji $\mathrm{R}^{2}$ (koefisien determinasi) dan uji regresi linier berganda. Peneliti menggunakan SPSS 26 for windows.

Sampel adalah bagian dari jumlah dan karekteristik yang dimiliki oleh populasi tersebut (Sugiyono, 2017). Teknik pengambilan sampel menggunakan dua cara yaitu Proportionate Stratetified Random Sampling dan Simple Random Sampling. Untuk penyebaran kuesioner dengan menggunakan teknik Simple Random Sampling. Proportionate Stratetified Random Sampling adalah teknik pengambilan sampel yang digunakan bila populasi mempunyai anggota/unsur yang tidak homogen dan berstrata secara proporsional (Sugiyono, 2017). Berikut ini adalah penentuan jumlah sampel menggunakan teknik sampel Proportionate Stratified Random Sampling.

Penentuan sampel digunakan teknik Simple Random Sampling. Pengambilan anggota dari populasi dilakukan secara acak tanpa memperhatikan strata yang ada dalam 
populasi itu. Cara demikian dilakukan bila anggota populasi dianggap homogen (Sugiyono, 2017)

\section{HASIL DAN PEMBAHASAN}

\section{Hasil Uji Validitas dan Reliabilitas}

Berdasarkan hasil uji validitas dapat diketahui semua item dalam penelitian dikatakan valid karena $r_{\text {hitung }}>r_{\text {tabel }}$. Sedangkan hasil uji reliabilitas dapat dilihat bahwa nilai cronbachs's alpha semua variabel dalam penelitian lebih besar dari 0,60 dan ini menandakan bahwa semua pernyataan yang digunakan ada penelitian ini bersifat reliabel.

\section{Analisis regresi linier berganda}

Regresi linear berganda digunakan untuk mengetahui arah hubungan antara variabel bebas yang diteliti terdri dari Disiplin Preventif $\left(\mathrm{X}_{1}\right)$, Disiplin Korektif $\left(\mathrm{X}_{2}\right)$ dan Disiplin Progresif (X3) terhadap variabel terikat yaitu Kinerja Karyawan (Y). lebih lanjut tabel 5 akan menejlaskan hasil regresi liner berganda. Berdasarkan olah data pada tabel 5 diatas dapat diketahui hasil uji regresi linier berganda sebagai berikut:

$$
\mathrm{Y}=1,342+0,279 \mathrm{X}_{1}+0,284 \mathrm{X}_{2}+0,107 \mathrm{X}_{3}
$$

Dimana :

1. Konstanta sebesar 1,342 diartikan bahwa jika X1, X2, X3 nilainya sama dengan 0, maka kinerja karyawan pada PTPN XIII (Persero) Pabrik Minyak Sawit Olongpinang tidak meningkatkan disiplin kerja sehingga disiplin kerja bernilai tetap.

2. Koefisien variabel $X_{1}$ sebesar 0,279 artinya disiplin preventif berpengaruh positif terhadap kinerja karyawan, sehingga apabila disiplin preventif pada PTPN XIII (Persero) Pabrik Minyak Sawit Olongpinang dinaikkan sebesar satu satuan maka kinerja karyawan akan naik sebesar 0,279 satuan.

3. Koefisien variabel $\mathrm{X}_{2}$ sebesar 0,284 artinya disiplin korektif berpengaruh positif terhadap kinerja karyawan, sehingga apabila disiplin korektif pada PTPN XIII (Persero) Pabrik Minyak Sawit Olongpinang dinaikkan sebesar satu satuan maka kinerja karyawan akan naik sebesar 0,284 satuan.

4. Koefisien variabel $X_{3}$ sebesar 0,107 artinya disiplin progresif berpengaruh positif terhadap kinerja karyawan, sehingga apabila disiplin progresif pada PTPN XIII (Persero) Pabrik Minyak Sawit Olongpinang dinaikkan sebesar satu satuan maka kinerja karyawan akan naik sebesar 0,107 satuan.

\section{Uji Simultan}

Berikut uji pengaruh secara simultan variabel disiplin di tabel 6. Uji F dilakukan dengan membandingkan $\mathrm{F}$ hitung dengan $\mathrm{F}$ tabel pada taraf nyata $\mathrm{a}=0,05$. Dari tabel diatas dapat disimpulkan bahwa $\mathrm{F}$ hitung sebesar 66,929 > dari $F$ tabel 2,69 yang berarti bahwa pada taraf nyata $\mathrm{a}=0,05$ variabel 
yang terdiri Disiplin Preventif $\left(\mathrm{X}_{1}\right)$, Disiplin Korektif $\left(\mathrm{X}_{2}\right)$ dan Disiplin Progresif $\left(\mathrm{X}_{3}\right)$ secara simultan terhadap kinerja Karyawan (Y) dapat diterima atau teruji pada taraf nyata a $=0,05$ sehingga hipotesis diterima sesuai proses pengujian, Apabila $F_{\text {hitung }}>F_{\text {tabel }}$, maka $\mathrm{H}_{0}$ ditolak dan $\mathrm{H}_{\mathrm{a}}$ diterima. Berarti variabel bebas secara bersama mempunyai pengaruh signifikan terhadap variabel terikat. Dapat disimpulkan bahwa semakin bagus disiplin preventif, disiplin korektif dan disiplin progresif maka akan semakin baik pula kinerja karyawan di PTPN XIII (Persero) Pabrik Minyak Sawit Olongpinang.

\section{Uji Parsial}

Uji pengaruh secara parsial disiplin preventif, disiplin korektif dan disiplin progresif dapat dilihat pada tabel 7. Pada tabel tersebut telah diperoleh $t_{\text {hitung }}$ dari setiap variabel. Selanjutnya nilai $t_{\text {tabel }}$ akan dibandingkan nilai $t_{\text {tabel, }}$ dengan $\mathrm{a}=0,05$ atau $5 \%$ dan dengan menggunakan rumus $\mathrm{df}=\mathrm{n}$ 2 maka nilai tabel nya adalah 1.667. Berikut uraian masing-masing variabel:

1. Pengaruh parsial dari variabel disipilin preventif $\left(\mathrm{X}_{1}\right)$ diperoleh dengan nilai 8,720. Karena nilai $\mathrm{t}$ hitung $>\mathrm{t}$ tabel sebesar 1,6595, dengan hasil tersebut maka $\mathrm{H}_{\mathrm{o}}$ ditolak dan $\mathrm{H}_{1}$ diterima, hal ini berarti variabel disipilin preventif berpengaruh terhadap kinerja karyawan di PTPN XIII (Persero) Pabrik Minyak Sawit Olongpinang.
2. Pengaruh parsial dari variabel disiplin korektif $\left(\mathrm{X}_{2}\right)$ diperoleh 8,003. Nilai $\mathrm{t}$ hitung $>\mathrm{t}$ tabel sebesar 1,6595, dengan hasil tersebut maka $\mathrm{H}_{\mathrm{o}}$ ditolak dan $\mathrm{H}_{2}$ diterima, hal ini berarti variabel disipilin korektif berpengaruh terhadap kinerja karyawan di PT. PTPN XIII (Persero) Pabrik Minyak Sawit Olongpinang.

3. Pengaruh parsial dari variabel disiplin progresif $\left(\mathrm{X}_{3}\right)$ diperoleh 2,364. Nilai $\mathrm{t}_{\text {hitung }}$ $>\mathrm{t}$ tabel sebesar 1,6595, dengan hasil tersebut maka $\mathrm{H}_{\mathrm{o}}$ ditolak dan $\mathrm{H}_{3}$ diterima, hal ini berarti variabel disipilin progresif berpengaruh terhadap kinerja karyawan di PT. PTPN XIII (Persero) Pabrik Minyak Sawit Olongpinang.

\section{Koefisien Korelasi dan Determinasi}

Koefisien Korelasi (R) dan Determinasi (R2) hasil regresi dapat dilihat pada tabel 8 . Berdasarkan tabel tersebut nilai $\mathrm{R}$ sebesar 0,810 menunjukkan bahwa hubungan yang sangat kuat antara variabel bebas yang terdiri dari Disiplin Preventif $\left(\mathrm{X}_{1}\right)$, Disiplin Korektif $\left(\mathrm{X}_{2}\right)$ dan Disiplin Progresif $\left(\mathrm{X}_{3}\right)$ terhadap variabel Kinerja Karyawan (Y). Nilai koefisien determinasi dari hasil regresi adalah sebesar 0,657, hal ini berarti $65,7 \%$ variabel terikat yaitu Kinerja Karyawan (Y) dipengaruhi oleh variabel bebas yang terdiri dari Disiplin Preventif $\left(\mathrm{X}_{1}\right)$, Disiplin Korektif $\left(\mathrm{X}_{2}\right)$ dan Disiplin Progresif $\left(\mathrm{X}_{3}\right)$ sedangkan $34,3 \%$ dipengaruhi oleh faktor lain. 


\begin{tabular}{|c|c|c|c|c|c|}
\hline \multirow{2}{*}{ Model } & \multicolumn{2}{|c|}{ Unstandardized Coefficients } & \multirow{2}{*}{$\begin{array}{c}\text { Standardized } \\
\text { Coefficients } \\
\text { Beta } \\
\end{array}$} & \multirow[t]{2}{*}{$\mathrm{t}$} & \multirow{2}{*}{ Sig } \\
\hline & B & Std. Error & & & \\
\hline \multicolumn{6}{|l|}{ Coefficients $^{a}$} \\
\hline (Constant) & & 0,214 & & 6,266 & 0,000 \\
\hline $\mathrm{X} 1$ & & 0,032 & 0,519 & 8,720 & 0,000 \\
\hline $\mathrm{X} 2$ & & 0,035 & 0,470 & 8,003 & 0,000 \\
\hline X3 & & 0,045 & 0,141 & 2,364 & 0,020 \\
\hline
\end{tabular}

Tabel 6

Hasil Uji F (Simultan)

\begin{tabular}{l|c|c|c|c}
\multicolumn{1}{c}{ Model } & Df & $F_{\text {hitung }}$ & $F_{\text {tabel }}$ & Sig. \\
Regression & 3 & 66,929 & 2,69 & $0,000^{b}$ \\
Residual & 105 & & & \\
Total & 108 & & & \\
\hline Sumber : Data Diolah, 2020 & &
\end{tabular}

Tabel 7

Hasil Uji T (Parsial)

\begin{tabular}{lccc}
\multicolumn{1}{c}{ Model } & $\mathrm{T}_{\text {hitung }}$ & $\mathrm{T}_{\text {tabel }}$ & Sig. \\
Disiplin Preventif (X1) & 8,720 & 1,65950 & 0,000 \\
Disiplin Korektif (X2) & 8,003 & 1,65950 & 0,000 \\
Disiplin Progresif (X3) & 2,364 & 1,65950 & 0,020 \\
\hline Sumber: Data Diolah, 2020 & & &
\end{tabular}

Tabel 8

Hasil Koefisien Determinasi

\begin{tabular}{ccccc} 
Model & R & R Square & $\begin{array}{c}\text { Adjusted } R \\
\text { Square }\end{array}$ & $\begin{array}{c}\text { Std. Error of the } \\
\text { Estimate }\end{array}$ \\
\hline Model Summary & & & & \\
\hline 1 & $0,810^{\mathrm{a}}$ & 0,657 & 0,647 & 0,23033 \\
\hline
\end{tabular}

Sumber : Data Diolah, 2020

\section{KESIMPULAN}

Berdasarkan hasil penelitian yang telah dilakukan peneliti mengenai Pengaruh Disiplin Kerja Terhadap Kinerja Karyawan Pada PTPN XIII (PERSERO) Pabrik Minyak Sawit Olongpinang Di Kecamatan Paser Belengkong, maka dapat ditarik kesimpulan sebagai berikut:
1. Dari hasil Uji Validitas diketahui bahwa korelasi antara masing-masing skor terhadap total skor dari setiap soal menunjukkan hasil yang valid.

2. Hasil Uji Reliabilitas menunjukkan bahwa semua variabel mempunyai Cronbach's Alpha yang cukup besar yaitu 0,733 sehingga dapat dikatakan semua konsep pengukur masing-masing 
variabel dari koesioner adalah realiabel sehingga untuk selanjutnya item-item pada masing-masing konsep variabel tersebut layak digunakan sebagai alat ukur.

3. Berdasarkan Hasil Regresi Linear Berganda :

$\mathrm{Y}=1,342+0,279 \mathrm{X}_{1}+0,284 \mathrm{X}_{2}+0,107 \mathrm{X}_{3}$ Konstanta sebesar 1,342 mempunyai arti Kinerja Karyawan akan meningkat sebesar 1,342 jika variabel Disiplin Preventif (X1), Disiplin Korektif (X2) dan Displin Progresif (X3) konstan atau tetap

4. Berdasarkan Hasil Nilai Koefisien Korelasi (R), nilai koefisien korelasi (R) sebesar 0,810 berada pada tingkat hubungan yang kuat antara variabel tidak bebas Kinerja Karyawan (Y) dengan variabel bebas Disiplin Preventif $\left(\mathrm{X}_{1}\right)$, Disiplin Korektif $\left(\mathrm{X}_{2}\right)$ dan Displin Progresif $\left(\mathrm{X}_{3}\right)$.

5. Berdasarkan Hasil Nilai Koefisien Determinasi $\left(\mathrm{R}^{2}\right)$, nilai koefisien determinasi $\left(R^{2}\right)$ sebesar 0,657 atau sebesar $65,7 \%$ yang berarti berada pada tingkat pengaruh yang kuat antara variabel bebas dengan variabel tidak bebas sebesar $65,7 \%$ sedangkan sisanya $34,3 \%$ dipengaruhi oleh variabel lain yang tidak terdapat dalam penelitian ini.

6. Berdasarkan Uji Simultan, didapat $F_{\text {hitung }}$ dari $F_{\text {tabel }}$ atau uji simultan sebesar 66,929 > dengan $F_{\text {tabel }} 2.69$ dengan tingkat signifikan 0,000. Karena $F_{\text {hitung }}>$ $\mathrm{F}$ tabel dengan demikian maka $\mathrm{H}_{0}$ ditolak
$\mathrm{H}_{\mathrm{a}}$ diterima, artinya terdapat pengaruh variabel independen yang signifikan terhadap variabel dependen, maka model regresi bisa dipakai untuk memprediksi Kinerja Karyawan atau dengan kata lain variabel Disiplin Preventif $\left(\mathrm{X}_{1}\right)$, Disiplin Korektif $\left(\mathrm{X}_{2}\right)$ dan Displin Progresif $\left(\mathrm{X}_{3}\right)$ secara simultan berpengaruh terhadap kinerja karyawan, sehingga hipotesis peneliti dalam penelitian ini diterima.

7. Berdasarkan Uji parsial diketahui bahwa variabel yang berpengaruh signifikan terhadap terhadap Kinerja Pada PT. Perkebunan Nusantara XIII (PERSERO) Pabrik Minyak Sawit Olongpinang Di Kecamatan Paser Belengkong adalah Disiplin Preventif (X1), dan diketahui pula bahwa berpengaruh dominan terhadap Kinerja Karyawan (Y) adalah Disiplin Preventif (X1) yaitu Nilai thitung sebesar 8,720> Nilai $t$ tabel sebesar 1,98282 dengan taraf signifikan 0,000.

\section{IMPLIKASI PENELITIAN}

Hasil penelitian yang menunjukkan disiplin kerja baik secara parsial maupun simultan berpengaruh terhadap kinerja karyawan pada PTPN XIII (PERSERO) Pabrik Minyak Sawit di Paser Belengkong, dapat dijadikan bahan pertimbangan bagi manajemen dalam membuat kebijakan untuk meningkatkan kinerja karyawan. Kedisiplinan kerja dalam menyelesaikan tugas dengan penuh tanggung jawab serta mematuhi peraturan yang telah ditetapkan oleh perusahaan 
sangat berpengaruh terhadap kinerja karyawan.

\section{ACKNOWLEDGEMENT}

Penulis mengucapkan terimakasih kepada Manager PT. Perkebunan Nusantara XIII Pabrik Minyak Sawit di Kecamatan Paser Belengkong serta beberapa pihak lain yang turut serta membantu dalam memberikan data dan informasi untuk keberlangsungan penelitian ini sehingga penelitian ini dapat selesai. Diharapkan penelitian ini dapat menambah khasanah ilmu pengetahuan dalam bidang Manajemen Sumber Daya Manusia.

\section{DAFTAR PUSTAKA}

Edison, Emron. Yohny anwar, Imas Komariyah. (2016). Manajemen Sumber Daya Manusia. Bandung: Alfabeta

Fahmi, Irham. (2011). Manajemen Sumber Daya Manusia Teori dan Aplikasi. Cetakan kedua. Bandung: Alfabeta

Handoko, T. Hani. (2011). Manajemen Personalia dan Sumberdaya Manusia. Edisi 2. Yogyakarta: BPFE Yogyakarta

Hasibuan, Malayu. (2013). Manajemen Sumber Daya Manusia. Cetakan ketujuh belas. Jakarta: PT Bumi Aksara

Hamali, Yusuf. (2018). Pemahaman Manajemen Sumber Daya Manusia Strategi Mengelola Karyawan. Cetakan ketiga. Jakarta: PT Buku Seru

Husna, Nikmatul. (2017). Pengaruh Disiplin Kerja Terhadap Kinerja Guru Pada SMAN 1 Canduang Kabupaten Agam. Jurnal EKOBISTEK Fakultas Ekonomi. (6) 2. 286-298

Mangkunegara, Prabu. (2013). Manajemen Sumber Daya Manusia Perusahaan. Cetakan ke-11. Bandung: Alfabeta

Poma, Maryam D. (2014). Disiplin Progresif di Kantor Camat Kota Selatan Gorontalo. Jurnal Manajemen Sumber Daya Manusia, Administrasi dan Pelayanan. (1) 2. 107 - 114

Prabu Mangkunegara, AA. Anwar. (2013). Manajemen Sumber Daya Manusia Perusahaan. Bandung: Remaja Rosdakarya

Pratiwi, Dian. Dkk. (2017). Pengaruh Disiplin Kerja Dan Lingkungan Kerja Terhadap Kinerja Pegawai Pada PT Bank Sumut Syariah Cabang Pematang Siantar. Jurnal MAKER, (3) 1, $73-81$

Puspitasari, Ayu. Wawan Prahiawan. (2018). Pengaruh Disiplin Preventif dan Motivasi Ektrinsik Terhadap Kinerja Karyawan Melalui Kepuasan Kerja Sebagai Variabel Intervaining Pada PT. Natura Indoland. Jurnal Tirtayasa Ekonomika, (13) 2, 339-356 
Safitriani. (2016). Pengaruh Disiplin Kerja Terhadap Kinerja Pegawai pada Dinas Pendidikan Pemuda dan Olahraga di Kab. Jeneponto. Manajemen, Fakultas Ekonomi dan Bisnis Islam UIN Alauddin Makassar

Sanjaya, Nicky. (2016). Pengaruh Disiplin Kerja Terhadap Kinerja Karyawan pada PT. Althap Tata Laksana Cabang Tanah Grogot Kabupaten Paser. Manajemen, Program Studi Manajemen STIE Widya Praja Tanah Grogot

Strauss and Sayles. (1977). Manajemen Personalia Segi Manusia Dalam Organisasi. Jakarta: Saptodadi

Sinambela, Poltak. 2016. Manajemen Sumber Daya Manusia. Cetakan pertama. Jakarta: PT Bumi Aksara

Sugiyono. (2017). Metode Penelitian Pendidikan (Pendekatan Kuantitatif, Kualitatif, dan RandD). Bandung: Alfabeta

Wiguna, Andri Prima. (2018). Pengaruh Disiplin Kerja Terhadap Kinerja Karyawan Pada Colony Corner Bandung. Manajemen, Fakultas Bisnis dan Manajemen Universitas Widyatama 